\title{
Peningkatan Prestasi Belajar Materi Pemahaman Ide Pokok Dalam Teks Melalui Penerapan Model Pembelajaran Auditory, Intellectually and Repetition (AIR)
}

\author{
Lusy Riyayani \\ SDN Wonokusumo VII/46 Surabaya \\ J1. Wonosari Lor Baru No.21 Kecamatan Semampir, Surabaya \\ lusyriyayani92@gmail.com
}

\begin{abstract}
The purpose of this study was to determine whether the application of the Auditory, Intellectually and Repetition (AIR) Learning Model has a positive impact on the learning achievement of Grade III-C students of SDN Wonokusumo VII/46 Surabaya. The research was carried out through a two-cycle mechanism using electronic learning media. Meanwhile, the students' learning achievement in Class III-C on the subject of understanding the main ideas in the text is the object of research that needs to be improved in this action research. Based on data analysis, from this study it can be concluded that there is an increase in learning achievement in the subject matter of Understanding the Main Ideas in Text and positive changes in student learning styles in the material of Understanding the Main Ideas in Text through the application of the Auditory, Intellectually and Repetition (AIR) Learning Model at SDN Wonokusumo VII/46 Surabaya with good category.
\end{abstract}

Keywords: Comprehension, Learning Model, Auditory, Intellectually and Repetition

\begin{abstract}
Abstrak
Tujuan penelitian ini adalah untuk mengetahui apakah penerapan Model Pembelajaran Auditory, Intellectually and Repetition (AIR) berdampak positif pada prestasi belajar siswa Kelas III-C SDN Wonokusumo VII/46 Surabaya. Penelitian dilaksanakan melalui mekanisme dua siklus dengan menggunakan media pembelajaran elektronik. Sedangkan prestasi belajar siswa Kelas III-C pada materi Pemahaman Ide Pokok dalam Teks menjadi obyek penelitian yang butuh ditingkatkan pada penelitian tindakan ini. Berdasarkan analisis data, dari penelitian ini dapat ditarik kesimpulan bahwa ada peningkatan prestasi belajar materi Pemahaman Ide Pokok dalam Teks dan perubahan positif gaya belajar siswa pada materi Pemahaman Ide Pokok dalam Teks melalui penerapan Model Pembelajaran Auditory, Intellectually and Repetition (AIR) di SDN Wonokusumo VII/46 Surabaya dengan kategori baik.
\end{abstract}

Kata kunci: Pemahaman, Model Pembelajaran, Auditory, Intellectually and Repetition

Copyright (c) 2020 Lusy Riyayani

$\triangle$ Corresponding author: Lusy Riyayani

Email Address: lusyriyayani92@gmail.com (Jl. Wonosari Lor Baru No.21 Kecamatan Semampir, Surabaya)

Received 28 Januari 2020, Accepted 30 Desember 2020, Published 30 Desember 2020

\section{PENDAHULUAN}

Belajar bahasa adalah bagian dari keterampilan vokasional, yang secara substansi bermakna belajar komunikasi. Oleh karena itu, pembelajaran bahasa diarahkan untuk meningkatkan kemampuan pebelajar dalam berkomunikasi, baik lisan maupun tulis (Depdikbud, 1995). Hal ini relevan dengan kurikulum 2013 bahwa kompetensi pebelajar bahasa diarahkan ke dalam empat subaspek, yaitu menyimak, berbicara, membaca, dan menulis. Oleh karena itu, setiap pengajar harus memiliki keterampilan dalam memilih strategi pembelajaran untuk setiap jenis kegiatan pembelajaran. Dengan demikian, pemilihan strategi pembelajaran yang tepat dalam kegiatan pembelajaran, diharapkan pencapaian tujuan belajar dapat terpenuhi. 
Gilstrap dan Martin (1975) menyatakan bahwa peran pengajar lebih erat kaitannya dengan keberhasilan pebelajar, terutama berkenaan dengan kemampuan pengajar dalam menetapkan strategi pembelajaran. Sedangkan tujuan pembelajaran bahasa, menurut Basiran (1999) adalah keterampilan komunikasi dalam berbagai konteks komunikasi. Kemampuan yang dikembangkan adalah daya tangkap makna, peran, daya tafsir, menilai, dan mengekspresikan diri dengan berbahasa. Kesemuanya itu dikelompokkan menjadi kebahasaan, pemahaman, dan penggunaan.

Uraian di atas sudah jelas bahwa pembelajaran bahasa pada anak didik atau pembelajar yang ditransformasikan oleh guru meliputi empat aspek yaitu menyimak, berbicara, membaca, dan menulis. Proses guru sendiri dalam mensransformasikan materi atau bahan untuk membantu siswa dalam menguasai atau mempelajari keempat aspek tersebut diserakan kepada guru sepenuhnya. Sehingga, sebagai guru dan calon guru sedini mungkin sudah harus diperkenalkan untuk berfikir kritis dan inovatif dalam mencari metode serta bahan ajar yang akan di sampaikan kepada paserta didik atau anak didik sesuai dengan tahap perkembangannya.

Berdasarkan observasi yang dilakukan di kelas III-C SDN Wonokusumo VII/46 Surabaya Tahun Pelajaran 2018/2019, dalam proses pembelajaran di kelas terlihat guru menjelaskan materi pembelajaran dan membahas contoh soal bersama siswa dan siswa mencatat materi dan contoh soal serta mengerjakan latihan yang diberikan oleh guru. Selama proses mengerjakan soal, terlihat siswa belum memahami konsep-konsep yang diberikan guru. Siswa juga kesulitan dalam mengaplikasikan konsep yang diberikan guru ketika diberi persoalan yang berbeda dari contoh soal. Keadaan ini terjadi disebabkan karena siswa hanya menghafal konsep-konsep yang diberikan tanpa memahaminya. Hal ini juga berkaitan dengan proses pembelajaran yang belum memberikan kesempatan kepada siswa dalam mengonstruksi pengetahuan, sehingga siswa hanya menerima konsep-konsep yang diberikan guru.

Permasalahan ini mengakibatkan rendahnya Prestasi Belajar Materi Pemahaman Ide Pokok dalam Teks yang diperoleh siswa. Sebagian besar siswa memperoleh nilai di bawah KKM. Mengacu pada permasalahan tersebut, maka dilakukan suatu penelitian yang dapat membuat siswa berperan aktif selama pembelajaran matematika yang sesuai dengan prestasi belajarnya. Salah satu solusi yang bisa digunakan adalah dengan menerapkan model pembelajaran Auditory Intellectually Repetition (AIR). Berdasarkan latar belakang yang telah dipaparkan di atas, dapat dirumuskan bahwa yang menjadi masalah dalam penelitian ini adalah sebagai berikut :

1. Apakah penerapan Model Pembelajaran Auditory, Intellectually and Repetition (AIR) berdampak positif pada prestasi belajar siswa Kelas III-C SDN Wonokusumo VII/46 Surabaya?

2. Apakah penerapan Model Pembelajaran Auditory, Intellectually and Repetition (AIR) dapat meningkatkan prestasi belajar siswa Kelas III-C pada materi Pemahaman Ide Pokok dalam Teks di SDN Wonokusumo VII/46 Surabaya? 


\section{Kajian Pustaka}

\section{Prestasi Belajar}

Nana Sudjana (2005) menyatakan bahwa prestasi belajar siswa pada hakikatnya adalah perubahan tingkah laku dan sebagai umpan balik dalam upaya memperbaiki proses belajar mengajar. Tingkah laku sebagai prestasi belajar dalam pengertian luas mencakup bidang kognitif, afektif dan psikomotorik. Suratinah Tirtonegoro (2001) mengemukakan prestasi belajar adalah penilaian hasil usaha kegiatan belajar yang dinyatakan dalam bentuk simbol, angka, huruf maupun kalimat yang dapat mencerminkan hasil yang sudah dicapai oleh setiap siswa dalam periode tertentu. Syaiful Bahri Djamarah (1996) mengungkapkan prestasi belajar adalah hasil yang diperoleh berupa kesan-kesan yang mengakibatkan perubahan dalam diri individu sebagai hasil dari aktivitas dalam belajar.

Eko Putro Widoyoko (2009), mengemukakan bahwa prestasi belajar terkait dengan pengukuran, kemudian akan terjadi suatu penilaian dan menuju evaluasi baik menggunakan tes maupun non-tes. Pengukuran, penilaian dan evaluasi bersifat hirarki. Evaluasi didahului dengan penilaian (assessment), sedangkan penilaian didahului dengan pengukuran.Benyamin Bloom (Sudjana, 2010) mengemukakan secara garis besar membagi prestasi belajar menjadi tiga ranah, yaitu ranah kognitif, ranah afektif dan ranah psikomotorik.

Tohirin (2006) mengungkapkan seseorang yang berubah tingkat kognitifnya sebenarnya dalam kadar tertentu telah berubah pula sikap dan perilakunya. Suharsimi Arikunto (2007) mengungkapkan ranah kognitif pada siswa SD yang cocok diterapkan adalah ingatan, pemahaman dan aplikasi, sedangkan untuk analisis, sintesis, baru dapat dilatih di SLTP dan SMU dan Perguruan Tinggi secara bertahap sesuai urutan yang ada. Pengetahuan atau ingatan merupakan proses berfikir yang paling rendah, misalnya mengingat rumus, istilah, nama-nama tokoh atau nama-nama kota. Kemudian pemahaman adalah tipe prestasi belajar yang lebih tinggi daripada pengetahuan, misalnya memberi contoh lain dari yang telah dicontohkan atau menggunakan petunjuk penerapan pada kasus lain. Sedangkan aplikasi adalah penggunaan abstraksi pada situasi kongkret atau situasi khusus. Menerapkan abstraksi yaitu ide, teori atau petunjuk teknis ke dalam situasi baru disebut aplikasi. Tujuan aspek kognitif berorientasi pada kemampuan berfikir yang mencakup kemampuan intelektual yang lebih sederhana, yaitu mengingat, sampai pada kemampuan memecahkan masalah yang menuntut siswa untuk menghubungkan dan menggabungkan beberapa ide, gagasan, model atau prosedur yang dipelajari untuk memecahkan masalah tersebut. Dengan demikian aspek kognitif adalah subtaksonomi yang mengungkapkan tentang kegiatan mental yang sering berawal dari tingkat pengetahuan sampai ke tingkat yang paling tinggi yaitu evaluasi.

\section{Pemahaman}

Pemahaman adalah hasil dari ranah tahu dan ini terjadi karena setelah seseorag melakukan penginderaan terhadap suatu obyek tertentu penginderaan terjadi melalui panca indera manusia yaitu penglihatan, pendengaran, penciuman, perabaan dan rasa. Sebagian besar pemahaman manusia 
melalui mata dan telinga (Bestable, 2002).

Dalam pengertian lain, pemahaman adalah berbagai gejala yang ditemui dan diperoleh manusia melalui pengamatan panca indera. Pemahaman muncul ketika seseorang menggunkan indera atau akal budinya utuk mengenali benda atau kejadian tertentu yang belum pernah dilihat atau dirasakan sebelumnya (Meliono, 2007).

Pemahaman merupakan hasil dari mengingat suatu hal, termasuk mengingat kembali kejadian yang pernah dialami baik secara sengaja maupun tidak sengaja dan terjadi setelah orang melakukan kontak atau pengamatan terhadap suatu objek tertentu (Mubarak, 2007).

Menurut Notoatmodjo (1993), Pemahaman mempunyai 6 tingkatan yang bergerak dari yang sederhana sampai yang kompleks

a) Tahu (Know). Tahu merupakan tingkat pemahaman yang paling rendah. Kata kerja untuk mengukur bahwa orang tahu tentang apa yang dipelajari antara lain: menyebutkan, menyatakan (Notoatmodjo, 1993).

b) Memahami (Understanding). Memahami diartikan sebagai suatu kemampuan untuk memahami dan menjelaskan secara benar arti suatu bahan pelajaran atau tentang obyek yang diketahui dan dapat diinterpretasikan materi tersebut secara benar, seperti menafsirkan, menjelaskan, meringkas tentang sesuatu. Kemampuan semacam ini lebih tinggi daripada tahu (Notoatmodjo, 1993).

c) Penerapan (Application). Penerapan adalah kemampuan menggunakan atau menafsirkan suatu bahan yang sudah dipelajari ke dalam situasi baru atau konkrit, seperti menerapkan suatu dalil, metode, konsep, prinsip, dan teori. Kemampuan ini lebih tinggi nilainya daripada pemahaman (Notoatmodjo, 1993).

d) Analisis (Analysis). Analisis adalah kemampuan untuk menguraikan atau menjabarkan sesuatu ke dalam komponen atau bagian-bagian sehingga susunannya dapat dimengerti. Kemampuan ini meliputi mengenal masalah-masalah, hubungan antar bagian, serta prinsip yang digunakan dalam organisasi materi pelajaran (Bestable, 2002).

e) Sintetis (Synthetic). Kemampuan sintetis merupakan kemampuan untuk menghimpun bagian ke dalam suatu keseluruhan, seperti merumuskan tema, rencana, atau melihat hubungan/abstrak dari berbagai informasi atau fakta. Jadi kemampuan merumuskan suatu pola atau struktur baru berdasarkan informasi dan fakta (Bestable, 2002).

f) Evaluasi (Evaluation). Evaluasi berkaitan dengan kemampuan untuk menggunakan pemahaman untuk membuat suatu penilaian terhadap sesuatu berdasarkan maksud atau kriteria tertentu. Kriteria yang digunakan dapat bersifat internal dan dapat bersifat relevan dengan maksud tertentu (Bestable, 2002) 


\section{Model Pembelajaran Auditory, Intellectually and Repetition (AIR)}

Huda (2003) berpendapat bahwa model pembelajaran AIR ini mirip dengan Somatic, Auditory, Visualitation, Intelectually (SAVI) dan Visualitation, Auditory, Kinestetic (VAK). Perbedaannya hanya terletak pada repetisi yaitu pengulangan yang bermakna pendalaman, perluasan, pemantapan dengan cara siswa dilatih melalui pemberian tugas atau kuis.

Menurut Suherman (dalam Humaira, 2012: 18) AIR adalah singkatan dari Auditory, Intelectually and Repetition. Pembelajaran seperti ini menganggap bahwa akan efektif apabila memperhatikan tiga hal tersebut. Auditory yang berarti bahwa indera telinga digunakan dalam belajar dengan cara mendengarkan, menyimak, berbicara, persentasi, argumentasi, mengemukakan pendapat dan menanggapi. Intectual berpikir yang berarti bahwa kemampuan berpikir perlu dilatih melalui latihan bernalar, mencipta, memecahkan masalah, mengkonstruksi dan menerapkan. Repetition yang berarti pengulangan, agar pemahaman lebih mendalam dan lebih luas, siswa perlu dilatih melalui pengerjaan soal, pemberian tugas atau kuis.

Berikut adalah penjelasan dari masing-masing tahap dalam model pembelajaran AIR:

a. Auditory. Auditory berarti belajar dengan melibatkan pendengaran. Mendengar merupakan salah satu aktivitas belajar, karena tidak mungkin informasi yang disampaikan secara lisan oleh guru dapat diterima dengan baik oleh siswa jika tidak melibatkan indera telinganya untuk mendengar. Sarbana (dalam Humaira, 2012) mengartikan auditory sebagai salah satu modalitas belajar, yaitu bagaimana kita menyerap informasi saat berkomunikasi ataupun belajar dengan cara mendengarkan. Sedangkan Meier (dalam Huda, 2003) pernah menyatakan bahwa pikiran auditoris lebih kuat daripada yang kita sadari. Telinga terus menerus menangkap dan menyimpan informasi auditoris, bahkan tanpa disadari. Langkah-langkahnya :

1) Guru membagi siswa menjadi beberapa kelompok kecil.

2) Guru membagikan LKS (Lembar Kerja Siswa) kepada siswa untuk dikerjakan secara kelompok.

3) Guru memberi kesempatan kepada siswa untuk bertanya mengenai soal LKS yang kurang dipahami.

b. Intellectually. Intellectually berarti menunjukkan apa yang dilakukan siswa dalam pikiran mereka secara internal ketika mereka menggunakan kecerdasan untuk merenungkan suatu pengalaman, menciptakan hubungan, makna, rencana, dan nilai dari pengalaman tersebut (Meier dalam Huda, 2003). Langkah-langkahnya :

1) Guru membimbing kelompok belajar siswa untuk berdiskusi dengan rekan dalam satu kelompok sehingga dapat menyelesaikan LKS.

2) Guru memberi kesempatan kepada beberapa kelompok untuk

3) Mempresentasikan hasil kerjanya. 
4) Guru memberikan kesempatan kepada kelompok lain untuk bertanya dan mengemukakan pendapatnya

c. Repetition. Repetition yaitu pengulangan yang bermakna pendalaman, perluasan, pemantapan siswa dengan cara memberinya tugas atau kuis. Bila guru menjelaskan suatu unit pelajaran, itu perlu diulang-ulang. Karena ingatan siswa tidak selalu tetap dan mudah lupa, maka perlu dibantu dengan mengulangi pelajaran yang sedang dijelaskan. Langkah-langkahnya :

1) Memberikan latihan soal individu kepada siswa.

2) Dengan diarahkan guru, siswa membuat kesimpulan secara lisan tentang materi yang telah dibahas

\section{METODE}

\section{Setting Penelitian}

Penelitian Tindakan Kelas (PTK) merupakan suatu proses dinamis yang berlangsung dalam satu atau lebih siklus, dan masing-masing siklus terdiri dari empat momen (fase) dalam spiral perencanaan, tindakan (action), observasi, dan refleksi yang oleh Kemmis dan McTaggart (1988) diilustrasikan dalam model PTK spiral. Dalam praktik, Kemmis dan McTaggart menyatakan model ini tidak boleh digunakan secara kaku, karena dalam kenyataan proses rencana - Tindakan - observasi - refleksi tersebut tidak berlangsung serapi model tersebut. Fase-fase itu biasanya berlangsung tumpang tindih. Dengan demikian penulis dapat memperbaiki strategi tersebut secara optimal sehingga pengimplementasian strategi revisi ini nantinya dapat mencapai semua target keberhasilan. Strategi yang sudah diperbaiki (revised strategy) inilah yang menjadi fase perencanaan (plan) pada siklus berikutnya, yang nantinya diimplemetasikan, diobservasi, dan direfleksi kembali. Siklus tersebut dapat diulang beberapa kali hingga seluruh kriteria keberhasilan tercapai. Jumlah siklus tidak dapat diprediksi pada awal penelitian. Jika setelah siklus pertama semua kriteria keberhasilan dapat dicapai maka penelitian dapat dihentikan. Namun selama kriteria-kriteria keberhasilan itu belum tercapai, revisi terhadap strategi perlu dilakukan dan siklus berikutnya dilaksanakan.

\section{Subjek Penelitian}

Penelitian ini dilaksanakan oleh penulis di SDN Wonokusumo VII/46 Surabaya. Pelaksanaan penelitian dijadwalkan oleh penulis dengan rincian jadwal sebagai berikut:

Tabel 1. Waktu Pelaksanaan Tindakan

\begin{tabular}{|l|c|c|c|c|}
\hline \multirow{2}{*}{\multicolumn{1}{|c|}{ Jenis Kegiatan }} & \multicolumn{4}{c|}{ Bulan/Minggu } \\
\cline { 2 - 6 } & Jul & Agt & Sep & Okt \\
\hline Konsultasi dengan Kepala Sekolah. & M3 & M1 & & M1 \\
\hline Mengajukan proposal penelitian. & M4 & & & \\
\hline Menyiapkan bahan Model Pembelajaran. & M4 & M4 & & \\
\hline Pelatihan penerapan Model Pembelajaran. & M4 & & & \\
\hline Observasi prestasi belajar siswa. & M4 & & & \\
\hline
\end{tabular}




\begin{tabular}{|l|c|c|c|c|}
\hline Pelaksanaan siklus I. & & M2 & & \\
\hline Refleksi siklus I. & & M3 & & \\
\hline Pelaksanaan siklus II. & & & M1 & \\
\hline Refleksi siklus II. & & & M2 & \\
\hline Menyusun laporan tindakan. & & & M3-4 & M1 \\
\hline
\end{tabular}

Kelas yang dijadikan obyek penelitian dan penelitian adalah Kelas III-C SDN Wonokusumo VII/46 Surabaya yang masih aktif pada tahun pelajaran 2018/2019 yang berjumlah 38 siswa.

\section{Teknik Pengumpulan Data}

Pengumpulan data PTK biasanya dilakukan dengan menggunakan (1) teknik dokumentasi, berupa data kelas, siswa dan perangkat pembelajaran guru, (2) teknik observasi, yang digunakan untuk mengukur atau menilai hasil dan proses belajar misalnya tingkah laku siswa pada proses belajar mengajar, serta (3) teknik tes yang digunakan secara tidak langsung. Dalam artian nilai tes dikonversikan sebagai bahan kajian kualitatif berdasarkan indikator yang dinilai.

\section{Validasi Data}

Validasi adalah suatu tindakan yang membuktikan bahwa suatu proses dapat memberikan hasil yang konsisten sesuai dengan spesifikasi yang telah ditetapkan dan terdokumentasi dengan baik. Validasi dilakukan bila ada perubahan yang mempengaruhi produk secara langsung (major modification), produk baru atau produk lama dengan metode baru, exiting dan legacy product. Konsep validitas dalam aplikasinya untuk penelitian tindakan mengacu kepada kredibilitas dan derajat keterpecayaan dari hasil penelitian. Salah satu langkah dalam prosedur untuk mendapatkan derajat kepercayaan ialah melalui validasi, yang dalam penelitian kualitatif disukai dengan istilah verifikasi. Menurut Borg dan Gall (2003) terdapat lima tahap kriteria validitas, yaitu: validitas hasil, proses, demokratis, katalis, dan dialog. Berdasarkan tahapan kriteria validitas, maka dalam penelitian ini validitas data menggunakan teknik Triangulasi Data. Triangulasi data yaitu mengecek keabsahan (validasi) data dengan mengkonfirmasikan data yang sama dari sumber yang berbeda untuk memastikan keabsahan.

\section{Teknik Analisis Data}

Teknik analisis data adalah kegiatan mencermati, menguraikan, dan mengkaitkan setiap informasi yang terkait dengan kondisi awal, proses belajar, dan hasil pembelajaran untuk memperoleh simpulan tentang keberhasilan tindakan perbaikan pembelajaran.

\section{Teknik Analisis Data Kuantitatif}

Pada data-data kuantitatif seperti nilai hasil belajar, skor angket, persentase, distribusi frekuensi yang dapat dilakukan dengan 2 cara yaitu : (1) Analisis secara deskriptif, analisis ini dilakukan dengan cara seperti menghitung jumlah, rata-rata, nilai persentase, dan membuat grafik, (2) Analisis secara statistik, analisis ini dilakukan dengan cara seperti menghitung nilai beda terkecil dan nilai korelasi antar variabel. 
Analisis data kuantitatif diperoleh dari hasil tes siswa yang bertujuan untuk mengetahui pemahaman siswa tentang materi pelajaran dari setiap siklus, di mana siswa secara individu telah belajar tuntas atau berhasil apabila sekurang-kurangnya mendapat nilai 3,0 (dengan nilai maksimal 4). Standar penentuan ketuntasan belajar siswa menurut Sudjana (2006:109) sebagai berikut :

$$
P=\frac{\sum x}{N} \times 100 \%
$$

Sedangkan untuk mencari persentase ketuntasan secara klasikal menggunakan rumus:

$$
P=\frac{\sum n}{N} \times 100 \%
$$

\section{Teknik Analisis Data Kualitatif}

Pada data kualitatif dapat dilakukan analisis :

a. Analisis Interaktif

Analisis ini dilakukan dengan : (1) memilih atau mereduksi data terhadap hasil temuan data yang relevan dengan penelitian diambil sementara data yang tidak relevan dibuang, (2) mendeskripsikan semua data yang relevan hasil temuan, dan (3) menarik kesimpulan berdasarkan deskripsi hasil temuan,serta (4) melakukan verifikasi

b. Analisis dengan mencari pola

Analisis ini dilakukan dengan cara mencarai pola berdasarkan hasil refleksi dari guru, kemudian digabung dengan data-data yang diperoleh pengamat pada saat observasi.

Dalam PTK, perhatian lebih pada kasus daripada sampel. Hal ini berimplikasi bahwa metodologi yang dipakai lebih dapat diterpkan terhadap pemahaman situasi problematik dari pada atas dasar prediksi di dalam parameter.

Analisis data dalam penelitian Kualitatif menggunakan statistik. Ada 2 macam statistik yang digunakan untuk analisis data dalam penelitian yaitu statistik deskriptif dan statistik inferensial

Statistik deskriptif adalah ststistik yang digunakan untuk menganalisis data dengan cara mendeskripsikan atau menggambarkan data yang telah terkumpul sebagai mana adanya tanpa bermaksud membuat kesimpulan yang berlaku umum. Penelitian yang dilakukan pada populasi (tanpa diambil sampelnya), jelas akan menggunakan ststistik deskriptif dalam menganalisisnya. Termasuk dalam ststistik deskriptif antara lain pengujian data melalui tabel, grafik, diagram lingkaran, pictogram. Perhitungan modus, median, mean, desil, persentil, perhitungn penyebaran data dan perhitungan persentase.

Statistik inferensial (sering juga disebut statistik induktif atau statistik probabilita) adalah teknik statistik yng digunakan untuk menganilisa data sampel dan hasilnya diberlakukan untuk populasi. Statistik ini akan cocok digunakan oleh sampel diambil dari populasi secara random. 
Salah satunya diterapkan pada instrumen lembar observasi. Lembar observasi yang diisi oleh pengamat pada saat mengamati proses pembelajaran berlangsung, baik pengamatan terhadap aktivitas guru maupun pengamatan terhadap aktivitas siswa dengan menggunakan rumus sebagai berikut :

$$
P=\frac{f}{N} \times 100 \%
$$

Pengelolahan kegiatan belajar mengajar dianalisis dengan ketentuan sebagai berikut:

$$
\begin{aligned}
& 1=\text { Kurang sekali } \\
& 2=\text { Kurang } \\
& 3=\text { Baik } \\
& 4=\text { Baik sekali }
\end{aligned}
$$

Data pengamatan dianalisis dengan menghitung rata-rata pada setiap siklus yang dilaksanakan, selanjutnya nilai rata-rata tersebut diklasifikasikan dengan kriteria sebagai berikut :

$$
\begin{array}{ll}
76-100 \% & =\text { Sangat baik. } \\
66-75 \% & =\text { Baik. } \\
46-65 \% & =\text { Cukup. } \\
0-45 \% & =\text { Kurang. }
\end{array}
$$

\section{Indikator Kinerja}

Indikator-indikator untuk menilai aktivitas guru adalah sebagai berikut:

Tabel 2. Indikator Aktivitas Guru (Diisi Oleh Observer atau Kepala Sekolah)

\begin{tabular}{|l|l|}
\hline No & \multicolumn{1}{|c|}{ Indikator Yang Dinilai } \\
\hline 1 & Memperjelas penyajian materi. \\
\hline 2 & Mengatasi keterbatasan ruang. \\
\hline 3 & Meningkatkan minat belajar siswa. \\
\hline 4 & Memberikan pengalaman belajar. \\
\hline 5 & Menerapkan banyak variasi media pembelajaran. \\
\hline
\end{tabular}

Sedangkan indikator-indikator untuk menilai prestasi belajar siswa adalah sebagai berikut :

Tabel 3. Indikator Prestasi Belajar Siswa

\begin{tabular}{|l|l|}
\hline No & \multicolumn{1}{|c|}{ Indikator Yang Dinilai } \\
\hline 1 & Memahami lewat membaca, mendengarkan dan mencocokkan. \\
\hline 2 & Memahami lewat gambar dan video. \\
\hline 3 & Memahami lewat pengalaman melakukan. \\
\hline
\end{tabular}

\section{Pembahasan}

\section{Deskripsi Kondisi Awal}

Pada akhir bulan Juli 2018 penulis melakukan observasi pada siswa Kelas III-C SDN Wonokusumo VII/46 Surabaya berkaitan dengan modus belajar siswa. Hal ini dilakukan untuk dapat diketahui jenis media pembelajaran yang sangat dibutuhkan mayoritas siswa. Temuan dari sosialisasi 
dan dokumentasi yang penulis dapatkan dari hasil observasi pada tabel berikut :

Tabel 4. Hasil Observasi Modus Belajar Siswa

\begin{tabular}{|l|l|c|c|}
\hline No & Indikator Yang Dinilai & Jumlah & $\%$ \\
\hline 1 & Memahami lewat membaca, mendengarkan dan mencocokkan. & 5 & $13 \%$ \\
\hline 2 & Memahami lewat gambar dan video. & 27 & $70 \%$ \\
\hline 3 & Memahami lewat pengalaman melakukan. & 6 & $17 \%$ \\
\hline \multicolumn{2}{|c|}{ Jumlah Siswa } & 38 & \\
\hline
\end{tabular}

Berdasarkan tabel 4 pengawas menginstruksikan penulis untuk melaksanakan penelitian tindakan kelas tentang keterkaitan modus belajar siswa dengan media pembelajaran yang digunakan guru. Oleh karenanya pada minggu itu juga penulis mengajukan proposal penelitian. Mengingat $70 \%$ siswa membutuhkan media pembelajaran berupa gambar dan video untuk memperoleh pemahaman materi maka penulis memutuskan untuk menyediakan media pembelajaran yang mengakomodasi unsur iconic dan juga symbolic, yaitu Model Pembelajaran Auditory, Intellectually and Repetition (AIR)

\section{Deskripsi Siklus I}

Pembelajaran pada siklus I dilaksanakan dalam waktu 2 x 4 x 35 menit. Pertemuan siklus I direncanakan pada hari Selasa, tanggal 7 dan 21 Agustus 2018, jam pelajaran 1 sampai dengan 4, dengan materi Pemahaman Ide Pokok dalam Teks pada pembelajaran Tematik. Pembelajaran pada siklus ini tentu saja menjadi pengalaman yang baru bagi siswa. Hal ini ditunjukkan dengan antusiasme mereka dalam belajar dan mengamati apa yang penulis sampaikan melalui Model Pembelajaran Auditory, Intellectually and Repetition (AIR), yaitu proyektor LCD. Kegiatan pengamatan terhadap konsep materi pembelajaran sedikit banyak membantu mereka untuk memahami materi secara utuh. Aktivitas guru dalam menggunakan Model Pembelajaran Auditory, Intellectually and Repetition (AIR) masuk dalam katagori cukup dengan nilai rata-rata 2,4 atau menguasai 60\% dari indikator yang diamati. Nilai terendah ada pada indikator 1 yaitu memperjelas penyajian materi dengan sub indikator yang dikarenakan minimnya pengalaman guru dalam menggunakan Model Pembelajaran Auditory, Intellectually and Repetition (AIR) ini saat penyampaian materi sehingga kebermanfaatan dari adanya Model Pembelajaran Auditory, Intellectually and Repetition (AIR) kurang tereksplorasi.

Selain bagi siswa, penerapan Model Pembelajaran Auditory, Intellectually and Repetition (AIR) ini merupakan hal yang baru bagi penulis sehingga sempat agak bingung bagaimana cara menyampaikan materi dengan menggunakan Model Pembelajaran Auditory, Intellectually and Repetition (AIR) pada siswa. Di samping itu, penulis sempat meragukan apakah dengan menggunakan Model Pembelajaran Auditory, Intellectually and Repetition (AIR) ini dapat merubah prestasi belajar siswa menjadi lebih aktif sehingga berpengaruh pada meningkatnya prestasi belajar siswa.

\section{Deskripsi Siklus II}

Pembelajaran pada siklus II dilaksanakan dalam waktu 2 x 4 × 35 menit. Pertemuan siklus II 
direncanakan pada hari Selasa, tanggal 4 dan 18 September 2018, jam pelajaran 1 sampai dengan 4, dengan materi Pemahaman Ide Pokok dalam Teks pada pembelajaran Tematik.

Pembelajaran pada siklus ini menjadi pengalaman yang menyenangkan bagi siswa. Hal ini ditunjukkan dengan antusiasme mereka dalam belajar dan mengamati apa yang penulis sampaikan dengan menerapkan Model Pembelajaran Auditory, Intellectually and Repetition (AIR). Kegiatan pengamatan terhadap konsep materi pembelajaran sedikit banyak membantu mereka untuk memahami materi secara utuh.

Aktivitas guru dalam menggunakan Model Pembelajaran Auditory, Intellectually and Repetition (AIR) masuk dalam katagori cukup dengan nilai rata-rata 2,8 atau menguasai $71 \%$ dari indikator yang diamati. Nilai terendah ada pada indikator 1 yaitu memperjelas penyajian materi dengan sub indikator yang dikarenakan minimnya pengalaman guru dalam menggunakan Model Pembelajaran Auditory, Intellectually and Repetition (AIR) ini saat penyampaian materi sehingga kebermanfaatan dari adanya Model Pembelajaran Auditory, Intellectually and Repetition (AIR) kurang tereksplorasi.

Selain bagi siswa, penerapan Model Pembelajaran Auditory, Intellectually and Repetition (AIR) ini merupakan hal yang baru bagi penulis sehingga sempat agak bingung bagaimana cara menyampaikan materi dengan menggunakan Model Pembelajaran Auditory, Intellectually and Repetition (AIR) pada siswa. Di samping itu, penulis sempat meragukan apakah dengan menggunakan Model Pembelajaran Auditory, Intellectually and Repetition (AIR) ini dapat merubah prestasi belajar siswa menjadi lebih aktif sehingga berpengaruh pada meningkatnya prestasi belajar siswa.

\section{Pembahasan}

Berdasarkan hasil observasi, menunjukkan bahwa prestasi belajar siswa dalam tes formatif pre-test dan post-test yang dilaksanakan sebelum dan sesudah tindakan pada siklus I. Yang perlu diperhatikan di sini adalah rata-rata pada pre-test sebesar 58 naik 5 atau $5 \%$ pada saat post-test, dan ketuntasan klasikal masih di bawah standar yaitu 35\% dengan 13 siswa yang tuntas.

Selanjutnya, berdasarkan hasil observasi, menunjukkan bahwa prestasi belajar siswa dalam tes formatif pre-test dan post-test yang dilaksanakan sebelum dan sesudah tindakan pada siklus II. Yang perlu diperhatikan di sini adalah rata-rata pada pre-test sebesar 63 naik 8 atau $8 \%$ pada saat post-test, dan ketuntasan klasikal masih di bawah standar yaitu $82 \%$ dengan 31 siswa yang tuntas.

Penerapan model pembelajaran Auditory, Intellectually and Repetition (AIR) sangat efektif digunakan untuk meningkatkan Prestasi Belajar dalam belajar pada materi merawat hewan dan tumbuhan di lingkungan sekitar siswa kelas III-C SDN Wonokusumo VII/46 Surabaya. Hal ini dibuktikan dengan meningkatnya siswa yang mencapai rata-rata skor minimum pada masing-masing indikator Prestasi Belajar yang telah ditentukan, dan juga meningkatnya ketuntasan klasikal yang tercapai apabila paling sedikit $75 \%$ siswa di kelas tersebut telah tuntas belajar.

Dalam upaya peningkatan Prestasi Belajar dalam penelitian tindakan ini telah dilaksanakan 
dalam dua tahap yang menunjukkan progresifitas ditilik dari ketercapaian individu maupun klasikal. Secara individu, rata-rata pencapaian ketuntasan klasikal mengalami kenaikan yang signifikan dari 15\% (kondisi prasiklus) menjadi 82\% (kondisi siklus II).

Tentu saja progresifitas ini membutuhkan upaya tindak lanjut agar dapat dibentuk pembiasaan dan budaya ilmiyah pada diri siswa ini melalui penerapan model pembelajaran Auditory, Intellectually and Repetition (AIR) maupun penerapan model, metode, strategi dan teknik serupa lainnya. Untuk mempermudah upaya tersebut seharusnya pendidik senantiasa mengembangkan kompetensi profesionalismenya dalam rangka mencari inovasi dan kreatifitas terbaru tentang model, metode, strategi dan teknik pembelajaran.

\section{KESIMPULAN}

Berdasarkan paparan hasil penelitian dan pembahasan, dapat dirumuskan kesimpulan yaitu : ada peningkatan prestasi belajar materi Pemahaman Ide Pokok dalam Teks dan perubahan positif prestasi belajar siswa pada materi Pemahaman Ide Pokok dalam Teks melalui penerapan Model Pembelajaran Auditory, Intellectually and Repetition (AIR) di SDN Wonokusumo VII/46 Surabaya dengan kategori baik.

Peningkatan tersebut disertai alternatif tindakan lain yaitu penyediaan media pembelajaran yang sesuai dengan modus belajar siswa, melaksanakan pelatihan penerapan Model Pembelajaran Auditory, Intellectually and Repetition (AIR) berbasis ICT untuk meningkatkan efektivitas penggunaan.

Oleh kerenanya, penulis memberikan beberapa saran agar kebutuhan guru dan siswa pada Model Pembelajaran Auditory, Intellectually and Repetition (AIR) dipenuhi oleh pemerintah-pemerintah daerah dalam rangka menunjang fasilitas pendidikan di daerah.. Guru seyogyanya sering memberi masukan kepada pengawas atau sebaliknya tentang berbagai upaya untuk meningkatkan hasil pembelajaran siswa melalui pelengkapan sarana prasarana sebagai media pembelajaran atau kebutuhan pembelajaran lainnya. Serta Kepala sekolah harus berani berinovasi dan berimprovisasi dalam pemenuhan kebutuhan pendidikan di sekolah terutama dalam kaitan dengan penyediaan sarana prasarana penunjang kegiatan pembelajaran agar tujuan pendidikan di sekolah dapat tercapai semaksimal mungkin.

\section{UCAPAN TERIMA KASIH}

Terimakasih kami ucapkan kepada Bapak/Ibu Kepala Sekolah dan Guru-guru di SDN Wonokusumo VI/45 Surabaya yang telah memberikan kesempatan kepada peneliti dalam melaksanakan penelitian. Terimakasih kepada siswa yang telah ikut berpartisipasi dalam melaksanakan penelitian ini.

\section{REFERENSI}

BSNP. 2007. Peraturan Menteri Pendidikan Nasional Republik Indonesia Nomor 16 Tahun 2007

Tentang Standar Kualifikasi Akademik dan Kompetensi Guru. Jakarta : BSNP. 
Meier, Dave. 2002. The Accelates Learning Handbook, terj. Rahmi Astuti. Bandung: Kaifa

Murdanu. 2004. Pengembangan Media Pembelajaran Matematika. Yogyakarta : UNY Press.

Ngalimun. 2013. Strategi dan Model Pembelajaran. Banjarmasin: Scripta Cendekia

Peraturan Menteri Pendidikan Nasional Republik Indonesia Nomor 41 Tahun 2007 Tentang Standar Proses untuk Satuan Pendidikan Dasar dan Menengah.

Peraturan Pemerintah Nomor 19 Tahun 2005 tentang Standar Nasional Pendidikan.

Sagala, H. Syaiful. 2006. Administrasi Pendidikan Kontemporer. Bandung : Alfabeta.

Sanjaya, Wina. 2008. Strategi Pembelajaran. Kencana Prenada Media Group. Jakarta.

Sudjana, H. Nana. 2009. Penelitian Tindakan Kepengawasan, Konsep dan Aplikasinya bagi Pengawas Sekolah. Jakarta: Binamitra Publishing.

Tim Penulis. 2006. Peraturan Menteri Pendidikan Nasional Nomor 22 Tahun 2006 Tentang Standar Isi. Jakarta: Depdiknas

Trianto. 2002. Model-model Pembelajaran Inovatif berorientasi konstruktivistik. Jakarta: Prestasi Pustaka

Undang-Undang Republik Indonesia Nomor 14 Tahun 2005 tentang Guru dan Dosen.

Undang-Undang Republik Indonesia Nomor 20 Tahun 2003 Tentang Sistem Pendidikan Nasional. 